\title{
Economic analysis of the finishing of lambs under confinement conditions using licuri cake (Syagrus coronata Mart. Becc.)
}

\section{Análise econômica da terminação de cordeiros em condições de confinamento utilizando torta de licuri (Syagrus coronata(Mart.)Becc.)}

COSTA $^{1}$, Jonival Barreto, OLIVEIRA ${ }^{1}$, Ronaldo Lopes, SILVA ${ }^{1}$, Thadeu Mariniello, RIBEIRO ${ }^{2}$, Ossival Lolato, RIBEIRO ${ }^{1}$, Rebeca Dantas Xavier, PINTO ${ }^{1}$, Luis Fernando Batista, NASCIMENTO' ${ }^{1}$, Thiago Vinicius Costa

${ }^{1}$ School of Veterinary Medicine and Animal Science, Federal University of Bahia, Adhemar de Barros, $\mathrm{n}^{\circ}$ 500, Ondina, Salvador - BA, CEP: 40.170110, e-mail: jonival@ufba.br,ronaldooliveira@ufba.br,thadeumsilva@gmail.com, rebecaribeiro@vetrinaria.med.br, luisfbp@gmail.com,thiagovcn@ufba.br.

${ }^{2}$ Campus de Zootecnia, Federal University of Reconcavo da Bahia, Rua Rui Barbosa, 710 - University Campus, Cruz das Almas - BA, 44380-000, email: ossribeiro@ yahoo.com.br.

\section{SUMMARY}

The present study endeavors to determine the impact of the inclusion of licuri tart in the diet of finishing lambs, Santa Inês mestizos, by evaluating the economic parameters. For this purpose, a total of 44 lambs, including both uncastrated as well as vaccinated and wormed lambs, with an average age of six months and a mean body weight of $21.2 \mathrm{~kg} \pm 2.7 \mathrm{~kg}$, were employed. Initially, the lambs were fed on the diet which consisted of $40 \%$ Tifton- 85 hay and $60 \%$ of a concentrated mixture, mainly composed of ground corn grain, soybean meal, mineral premix, being further followed by the inclusion of the licuri cake at four different levels (a) 0.0, (b) 8.0,(c) 16.0, and (d) $24 \%$ with respect to the dry matter. Principally, the soybean meal and milled corn were replaced by the licuri cake with these levels, thereby constituting four treatments and 11 replicates (11 lambs per treatment) in a completely randomized design. Further, for subjecting the lambs to the above mentioned four different levels of treatment, the lambs were confined for 70 days. The analysis of various economic parameters revealed that upon including the licuri cake up to the level of $24 \%$, the operation cost decreases, which in turn results in higher profitability. However, its cost at the time of use will eventually determine its use for feeding lambs, because of the possible price variations of the ingredients used to formulate the diets along with the model of production of the rural property.

\section{Animal Production and Environment}

Received on: 14/11/2018. Accepted on: 27/03/2019 Página | 1
Key words: Byproducts, nutrition, sheep, oilcakes.

\section{RESUMO}

Objetivou-se determinar o impacto da inclusão datorta de licuri na dieta de cordeiros em terminação, mestiços de Santa Inês, com base na analise econômica.Utilizou-se 44 cordeiros, não-castrados, vacinados e vermifugados, com média de seis meses de idade e peso corporal médio de $21,2 \mathrm{~kg} \pm 2,7 \mathrm{Kg}$. Os cordeiros foram alimentados com $40 \%$ feno de Tifton- 85 e $60 \%$ de uma mistura concentrada composta por grão de milho moído, farelo de soja, premix mineral e inclusão de torta de licuri nos níveis $0 ; 8 ; 16$ e $24 \%$ com base na matéria seca em substituição ao farelo de soja egrão de milho moído, com esses níveis constituindo os tratamentos, utilizando-se 11 cordeiros por tratamento em delineamento inteiramente casualizado. Os animais foram confinados por 70 dias. $\mathrm{O}$ menor custo operacional e consequente maior lucratividade quando se incluiu a torta de licuri até o nível de $24 \%$. No entanto, a decisão de seu emprego na alimentação de cordeiros vai depender de seu custo no momento da utilização, considerando as possíveis variações de preços dos ingredientes utilizados para formulação das dietas e modelode produção da propriedade rural.

Palavras-chave : Subprodutos, nutrição, ovinos, tortas oleaginosas. 


\section{INTRODUCTION}

The rising demand, tradition, the possibility of integration with other activities, as well as access to market niches and the aggregation of value have become the main structuring points due to which the interest in the sheep production chain has grown tremendously (Viana et al., 2013). These aspects are evidently visible due to the acceleration in search of the rural producers for technological alternatives, which have the capability to improve the productivity and the quality of the herds so as to meet this internal demand.

Among the various possible ways, the sheep production in an intensive or semiintensive way has been frequently identified, as one of the most promising possibilities as it utilizes lower cost rations such as some by-products or co-products from agro-industry. Typically, these byproducts or co-products are being derived, from the production of oils utilized for various other purposes, being in the food and cosmetics industry or in the production of biofuels. Predominantly, the environmental and economic issues have led to the growth of interest in using agroindustrial by-products in ruminant feed (Rodrigues et al., 2003; Azevedo et al., 2012; Gonzaga Neto et al., 2015; Medeiros et al., 2015). Additionally, the use of byproducts of biofuels as alternative sources of nutrition has been greatly driven, by the growing search for sustainable production, which basically includes environmental protection, social and economic inclusion (Morais et al., 2015; Oliveira et al., 2015; Silva et al., 2015).

Concerning the performance aspects, the economic analysis of investments has been highlighted as an important evaluation tool as it possibly affirms the viability of a project, apart from allowing the classification among the projects or evaluating the alternatives of action, thereby picking the more attractive among the several presented (Rodrigues et al., 2003; Santos, 2010). Santos et al. (2009) have also drawn attention towards the necessity of a good cost analysis system, as a basic and essential tool, required for the administration of any enterprise, especially in agribusiness. In such systems, the costs and revenues can constantly vary due to which the analysis becomes more complex and need to be analyzed differently from other types of business.

In the present investigation, mainly the nutritional composition of the licuri tortilla have urged the identification of its potential in ruminant feed (Ribeiro et al., 2008). But studies evaluating the economic viability of the use of licuri cake as an ingredient in the finishing diet of confined lambs are scarce in the literature. Therefore, the study involving the economic analysis of the concentrate levels in the finishing diet of confined lambs is of paramount importance (Barros et al., 2005). Thus, the present work makes an attempt to evaluate the effects of the inclusion of licuri cake on lambs in finishing from the perspective of economic analysis.

\section{MATERIAL AND METHODS}

\section{Local}

For carrying out the experiment, the Experimental Farm of the School of Veterinary Medicine and Animal Science of the Federal University of Bahia, located at $\mathrm{km} 174$ of BR 101 highway, in the municipality of São Gonçalo dos Campos (BA), was employed, with the experiment being carried out for a period of 88 days between August (2012) to November (2012).

\section{Animals and Experimental Management}

In the present work, all the experiments were carried out with the approval of the

\section{Animal Production and Environment}

Received on: 14/11/2018. Accepted on: 27/03/2019 Página|2 
ethics committee of the School of Veterinary Medicine and Animal Science of the Federal University of Bahia, with the registration of approval under protocol $\mathrm{n}^{\circ}$. $02 / 2014$. For the experiment, a total of 44 lambs including both crossbred as well as vaccinated and vermifuge crossbred lambs, with an average age of six months and mean initial weight of $21.2 \pm 2.7 \mathrm{~kg}$, were utilized. Further, the distribution of these lambs was carried out in a completely randomized design, comprising of four treatments and 11 replicates. Prior to the experiment, identification of all the animals was followed, by the treatment of all the lambs against (i) internal parasites and external parasites with ivermectin, Ivomec ${ }^{\circledR}$ Merial, (trematodes, nematodes, and mites), (ii) vaccination with the polyvalent vaccine, Poli-star® Valeé, (clostridia), and (iii) treatment for coccidiosis with sulfaquinoxaline. In total, the experiment lasted for 88 days, out of which 18 days were for adaptation and the remaining 70 days for sample collection.

Further, for housing animals, a fully covered area, being equipped with individual slatted and suspended floor bays along with individual feeders and drinking fountains, was utilized. The housed lambs were further offered diets in two equal daily fractions, (i) at 9:00 am and (ii) at 4:00 p.m, with the diet being provided in the form of a complete mixture (roughage:concentrate ratio established at 40:60), thereby minimizing selection by the animals. Moreover, to determine the consumption and the adjustment of the food provided, the leftovers were being weighed, on a daily basis, with the leftover being estimated to be approximately $15 \%$. On the other hand, the water was being given to the lambs as often as necessary.

\section{Experimental Diets}

The diet upon which the lambs were fed included Tifton-85 hay and a concentrated mixture, composed of milled corn grain, soybean meal, mineral premix and inclusion of licuri cake. Further, in partial substitution to the soybean meal and the ground corn grain, the treatment based on the dry matter consisted of levels, (a) $0.0 \%$, (b) $8.0 \%$, (c) $16.0 \%$, and (d) $24.0 \%$. However, before offering to the lambs, the roughage source \{Tifton-85 hay (Cynodon sp.)\}, was being crushed into particles of approximately 5.0 $\mathrm{cm}$, and the concentrated ingredients were mixed, in an automatic feed mixer. Subsequently, both the crushed hay and the homogeneous mixture of the concentrated ingredients, at the time of the tender, were mixed. Eventually, the licuri cake, before homogenization, was milled to break the clods and facilitate homogenization with the other ingredients of the concentrate. Additionally, the diets were being formulated to be isonitrogenated $(16.0 \%$ $\mathrm{CP})$ and isoenergetically (64\% TDN) to nutritional requirements for lambs, with an average weight gain of $200 \mathrm{~g} /$ day (NRC, 2007) (see Table 1). 
Rev. Bras. Saúde Prod. Anim., Salvador, v.20, 01 - 15, e0252019, 2019 http://dx.doi.org/10.1590/S1519-9940200252019

Table 1. Table showing theproportion and chemical composition of the ingredients and chemical composition of the experimental diets of lambs in finishing with licuri cake

\begin{tabular}{lcccc}
\hline Ingredients & \multicolumn{4}{c}{ Levels of licuri cake (\% DM) } \\
\cline { 2 - 5 } & $0 \%$ & $8 \%$ & $16 \%$ & $24 \%$ \\
\hline Groundcorn & 40.31 & 35.55 & 30.79 & 26.03 \\
Soybeanmeal & 17.19 & 13.95 & 10.71 & 7.47 \\
Licuri cake & 0 & 8 & 16 & 24 \\
Mineral supplement ${ }^{1}$ & 1.50 & 1.50 & 1.50 & 1.50 \\
Urea $^{+} \quad$ Ammonia & 1 & 1 & 1 & 1 \\
Sulphate & & & & 40 \\
Tifton-85 Hay & 40 & 40 & 40 & 40 \\
\hline
\end{tabular}

Chemicalcomposition

\begin{tabular}{|c|c|c|c|c|c|c|c|c|}
\hline \multirow{2}{*}{$\begin{array}{l}\text { Analyticalfr } \\
\text { actions }\end{array}$} & \multicolumn{4}{|c|}{ Ingredients } & \multicolumn{4}{|c|}{ Levels of licuri cake (\% DM) } \\
\hline & $\begin{array}{l}\text { Ground } \\
\text { corn }\end{array}$ & $\begin{array}{c}\text { Soybean } \\
\text { meal }\end{array}$ & $\begin{array}{c}\text { Licuri } \\
\text { cake }\end{array}$ & Hay & $0 \%$ & $8 \%$ & $16 \%$ & $24 \%$ \\
\hline DM (\%) & 88.05 & 89.06 & 87.15 & 91.18 & 89.77 & 89.67 & 89.56 & 89.46 \\
\hline $\mathrm{MM}^{3}$ & 1.20 & 6.26 & 5.91 & 6.08 & 5.49 & 5.7 & 5.92 & 6.13 \\
\hline $\mathrm{CP}^{3}$ & 6.73 & 49.75 & 24.24 & 5.1 & 16.1 & 16.11 & 16.12 & 16.13 \\
\hline $\mathrm{EE}^{3}$ & 4.53 & 1.88 & 13.86 & 1.13 & 2.6 & 3.43 & 4.27 & 5.10 \\
\hline NDFap $^{3}$ & 13.1 & 16.82 & 48.31 & 75.23 & 38.26 & 40.96 & 43.66 & 46.35 \\
\hline $\mathrm{ADF}^{3}$ & 5.00 & 11.78 & 30.63 & 38.05 & 19.26 & 21.09 & 22.92 & 24.75 \\
\hline $\operatorname{PIND}^{4}(\% \mathrm{CP})$ & 21.28 & 11.07 & 13.69 & 38.63 & 25.93 & 25.66 & 25.38 & 25.1 \\
\hline $\operatorname{PIAD}^{4}(\% \mathrm{CP})$ & 10.18 & 5.97 & 3.61 & 6.86 & 7.87 & 7.48 & 7.1 & 6.71 \\
\hline Lignin & 1.22 & 0.85 & 11.99 & 5.36 & 3.12 & 3.93 & 4.74 & 5.55 \\
\hline Cellulose & 3.78 & 8.97 & 18.63 & 32.69 & 16.14 & 17.16 & 18.18 & 19.2 \\
\hline Hemicelllose & 8.1 & 5.05 & 17.68 & 37.18 & 19.01 & 19.87 & 20.74 & 21.6 \\
\hline $\mathrm{NFC}$ & 74.44 & 25.29 & 7.68 & 12.46 & 37.55 & 33.8 & 30.03 & 26.29 \\
\hline $\mathrm{TDN}^{5}$ & 87.67 & 73.73 & 76.17 & 41.85 & 64.75 & 64.29 & 63.82 & 63.35 \\
\hline CDM, g/d ${ }^{6}$ & ------- & ------ & ------ & ----- & 1195.37 & 1102.28 & 877.22 & 658.26 \\
\hline $\mathrm{FC}(\mathrm{Kg} / \mathrm{Kg})^{6}$ & ------- & ------- & ------ & ----- & 6.34 & 5.51 & 5.76 & 6.98 \\
\hline $\mathrm{TWG}(\mathrm{Kg})^{6}$ & ------- & ------ & ------ & ----- & 16.58 & 15.51 & 13.68 & 11.2 \\
\hline
\end{tabular}

${ }^{1}$ Guarantee levels (per kg in active ingredients): calcium 120.0g; phosphorus $87.0 \mathrm{~g}$; sodium $147.0 \mathrm{~g}$; sulfur $18.0 \mathrm{~g}$; copper $590.0 \mathrm{mg}$; cobalt $40.0 \mathrm{mg}$; chromium $20.0 \mathrm{mg}$; iron $1,800.0 \mathrm{mg}$; $80.0 \mathrm{mg}$ iodine; manganese $1,300.0 \mathrm{mg}$; selenium, $15.0 \mathrm{mg}$; zinc $3,800.0 \mathrm{mg}$; 300.0mg molybdenum; maximum fluoride $870.0 \mathrm{mg}$; Solubility of phosphorus (P) in citric acid at $2 \%$ minimum $-95 \%{ }^{2}$ Mixture of urea and ammonium sulphate in a ratio of $9: 1 ;{ }^{3}$ Data in relation to percentage of Dry Matter; ${ }^{4}$ Protein insoluble in neutral detergent and Protein insoluble in acid detergent; ${ }^{5}$ Values estimated based on NRC equations (2001); ${ }^{6}$ Feed conversion data from Costa et al. (2016).

\section{Chemical Analysis}

With the aim of arrying out chemical analysis, the pre-drying of samples of ingredients in a forced ventilation oven at $55^{\circ} \mathrm{C}$ for 72 hours was followed, by the subsequent crushing of the samples in Willy knife mills with a $1.0 \mathrm{~mm}$ sieve, with the crushed samples being stored in labeled plastic flasks. The crushed stored samples were then submitted for analysis using various methods such as (i) dry matter

Animal Production and Environment

Received on: 14/11/2018. Accepted on: 27/03/2019 Página |4 
(DM) method 967.03, (ii) mineral matter (MM) method 942.05, (iii) crude protein (CP) method 981.10, (iv) ethereal extract (EE) method 920.29 (AOAC, 1990). Further, the methodology of Van Soest et al. (1991) with modifications proposed by the Ankon device manual of the Ankon Technology Corporation, was adopted for determining neutral detergent fiber (NDF) and acid detergent fiber (ADF). Additionally, the NDF was corrected, for ashes and protein, for which the neutral detergent boiling residue was muffled at $600{ }^{\circ} \mathrm{C}$ for 4.0 hours, and the protein insoluble in neutral detergent (PIND) content was subtracted, for determining the protein correction. Further, the non-fibrous carbohydrates (NFC) of the ingredients were calculated, according to Mertens (1994), by considering the calculation for the corrected NDF value for ash and protein. On the other hand, the lignin on the ADF residue was calculated, according to method 973.18 (AOAC, 1998), by employing $72 \%$ sulfuric acid. Likewise, the content of protein insoluble in neutral detergent (PIND) and protein insoluble in acid detergent (PIAD) was obtained, according to the recommendations of Licitra et al. (1996). Lastly, the TDN contents highlighted in Table 1 were calculated, according to the digestibility estimation formulas given for each analytical fraction (NRC, 2001), in the following way:

$$
\begin{gathered}
\mathrm{DNFC}=0.98(\% \mathrm{CNF}), \mathrm{DCP}=\% \mathrm{CP} \times[1-(0.4 \times \mathrm{PIAD} / \mathrm{CP})] \\
\mathrm{DE}=\% \mathrm{EE}-1, \mathrm{DNDF}=0.75 \times(\% \mathrm{NDFp}-\% \text { Lignin }) \times[1-(\% \text { Lignin } / \% \mathrm{NDFp}) 0.667]-7
\end{gathered}
$$
where,

DNFC =DigestibleNon-fibrous Carbohydrates;

$\mathrm{EED}=$ Digestible Ethereal Extract;

$\mathrm{DCP}=$ Digestible Crude Protein;

DNDF $=$ Digestible Neutral Detergent Fiber;

NDFp $=$ Neutral Detergent Fiber corrected for protein .

Following the estimation of the digestible analytical fractions, the TDN was estimated by using the equation given below:

$$
\mathrm{TDN}=\mathrm{DCP}+(2.25 \times \mathrm{DEE})+\mathrm{DNDF}+\mathrm{DNFC}
$$

where, TDN $=$ Total Digestible Nutrients, estimated according to NRC (2001).

However, the equation shown below was employed for calculating the total digestible nutrient contents (TDN):

$$
\operatorname{TDN}(\%)=(\text { TDNintake } / \text { DM intake }) \times 100 \text {. }
$$

Moreover, all the prices mentioned in Table

\section{Economic Analysis}

For analyzing the study economically, the performance of the animal was taken into consideration for calculating the financial return. Therefore, in view of obtaining the total feed costs, all the data were recorded in terms of prices $(\mathrm{R} \$)$, such as the price of (a) per kilogram of the ingredients of the diets, (b) per kilogram of marketed meat, (c) cost of the animals distribution in the treatments, (d) the products used for animal health, and (e) the labor required throughout the process (see Table 2).
2 , were obtained by carrying out the experiment in August 2012, in the Municipality of Feira de Santana/Ba. Subsequently, the costs of feed (CF) were calculated, by inserting the above values in the formula given below:

Confinement period) $\mathrm{x}$ CDex]

$$
\mathrm{CF}=[(\mathrm{DMIi} \quad \mathrm{x}
$$

where, DMIi = individual Dry Matter Intake; Confinement period $=70$ days; and CDex $=$ cost of the experimental diet in $\mathrm{R} \$ / \mathrm{kg}$.

Eventually, for calculating the Gross Income (GI), the carcass yields of each animal $(\mathrm{kg})$ were multiplied by the market

\section{Animal Production and Environment}

Received on: 14/11/2018. Accepted on: 27/03/2019 Página |5 
price $(\mathrm{R} \$ 9.50)$ paid for per kilogram of the

carcass.

Table 2. Table presenting the total feed costs, in absolute values, $(\mathrm{R} \$ / 100 \mathrm{~kg}$ dry matter (DM)), for finishing lambs submitted to diets with licuri cake.

\begin{tabular}{llcccc}
\hline Ingredients & $\begin{array}{l}\text { R\$/kg Ingredient } \\
\text { DM }\end{array}$ & \multicolumn{4}{c}{$\begin{array}{l}\text { Cost of DM in R\$/100 kg of diet } \\
\text { Inclusion Level (\% of DM) }\end{array}$} \\
\cline { 3 - 6 } & & 0.00 & 8.00 & 16.00 & 24.00 \\
\hline Ground Corn Grain & 0.74 & 29.83 & 26.31 & 22.78 & 19.26 \\
Soybean meal & 1.35 & 23.21 & 18.83 & 14.46 & 10.08 \\
Licuri Cake & 0.77 & 0.00 & 6.16 & 12.32 & 18.48 \\
Mineral supplement & 3.00 & 4.50 & 4.50 & 4.50 & 4.50 \\
Urea & 0.76 & 0.76 & 0.76 & 0.76 & 0.76 \\
Tifton-85 Hay & 0.76 & 30.40 & 30.40 & 30.40 & 30.40 \\
Total/100Kg of diet & & 88.70 & 87.00 & 85.20 & 83.50 \\
\hline
\end{tabular}

For calculating the operating cost (OC), the expenses of feed, vaccines, medicines, and labor, were added and further operating net revenue (ONR) was obtained, by subtracting the calculated OC from GR. Subsequently, by dividing the difference between GR and OC with the GR, followed by multiplication of the result with 100, the profitability assessment was evaluated. Further, the division of the ONR with the OC defines the cost-benefit ratio, used for comparing the values of the carcass weight. Moreover, by dividing the $\mathrm{OC}$ by the price per kilogram of the carcass, the leveling point was obtained. Overall, the analysis of the variables related to the economic cost of the experiment was carried out according to Nogueira, (2007).

\section{Statistical Analysis}

The results obtained from the economic analysis of the experiment were analyzed statistically, by subjecting the results to the analysis of variance (ANOVA), and regression up to $5.0 \%$ of probability, using the SASversão 9 program.

\section{RESULTS AND DISCUSSION}

The various analysis, being carried out in the present study, revealed that even though the roughage:concentrate ratio (40:60) did not vary among diets, the acquisition costs of each concentrate ingredient influenced the feed costs with the inclusion of licuri cake levels (see Table 2). Upon transforming these costs into percentage values for each ingredient, a decrease in the contribution of the soybean meal and corn grain in the cost of the diet, as well as an increase in the contribution of the hay and the licuri cake in these costs, with the increase of the level of inclusion of licuri cake, was observed (see Table 3 and Figure 1). Moreover, while mentioning the chemical composition of the experimental diets of lambs in finishing with licuri cake levels, the licuri cake was also included in Table 1.

\section{Animal Production and Environment}

Received on: 14/11/2018. Accepted on: 27/03/2019 Página | 6 


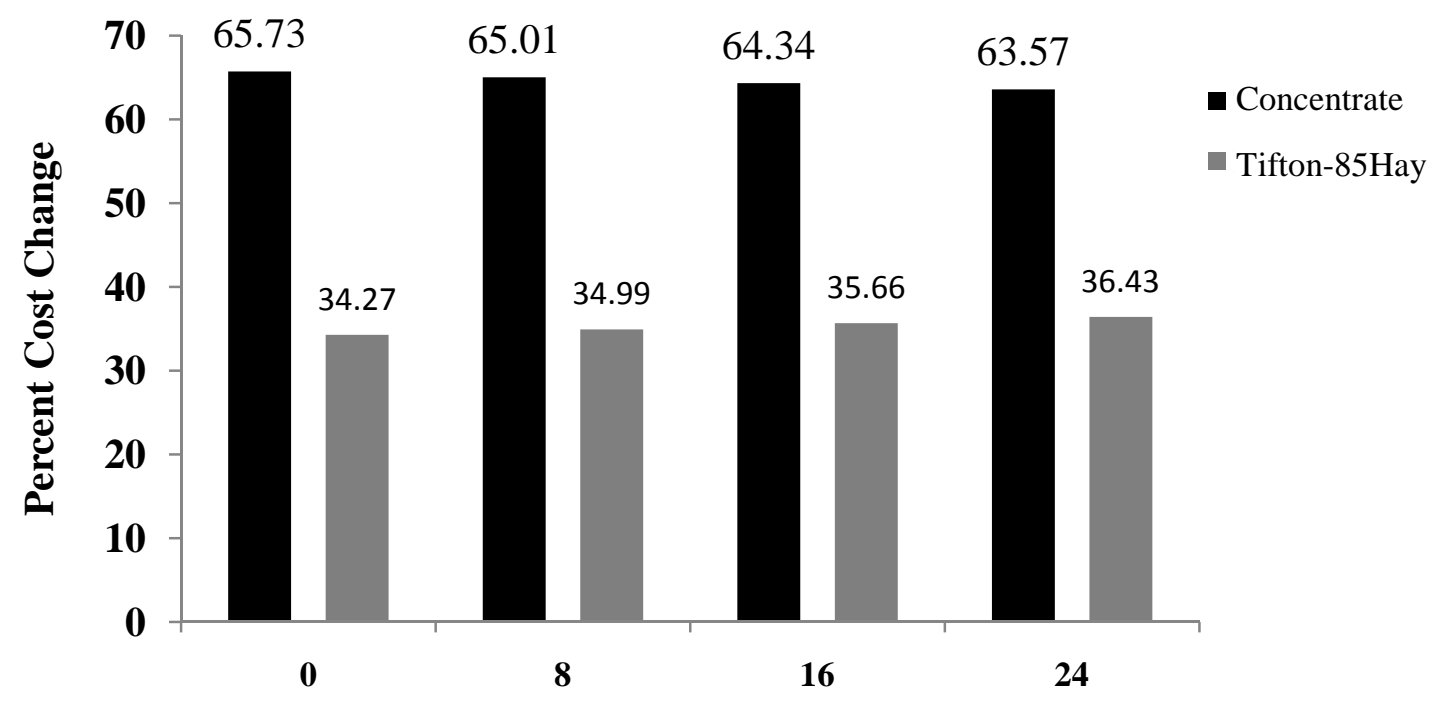

Licuri Cake inclusion levels

Figure 1.Percentage of the share of roughage and concentrate, in reais, on feed costs in finishing lambs fed diets with licuri cake.

Table 3. Table depicting the feeding costs, in percentages, of finishing lambs submitted to diets with differentlevels of inclusion of licuri cake.

\begin{tabular}{lcccc}
\hline Ingredients & \multicolumn{4}{c}{ Licuri cake inclusion levels (\% of DM) } \\
\cline { 2 - 5 } & 0.00 & 8.00 & 16.00 & 24.00 \\
\hline Grounded corn grain & Cost sharing in\% / Ingredient & & \\
Soybean meal & 33.63 & 30.24 & 26.74 & 23.07 \\
Licuri Cake & 26.17 & 21.64 & 16.97 & 12.07 \\
Mineral supplement & 0.00 & 6.95 & 14.16 & 21.69 \\
Urea & 5.07 & 5.17 & 5.28 & 5.39 \\
Total concentrate & 0.86 & 0.87 & 0.89 & 0.91 \\
Tifton-85 Hay & 65.73 & 65.01 & 64.34 & 63.57 \\
Total & 34.27 & 34.94 & 35.68 & 36.41 \\
\hline
\end{tabular}

Taking into consideration the evidenced costs, one can observe that upon replacing the soybean meal and grounded corn grain with the licuri cake in the sheep diet, the concentrate's share of feed costs decreased (see Table 4). Moreover, this decrease can be explicated by the lower acquisition cost per $\mathrm{kg}$ of DM of the licuri cake(R\$ 0.77), in comparison to the soybean meal ( $\mathrm{R} \$ 1.35)$, even with the purchase price of ground corn being $\mathrm{R} \$ 0.74 / \mathrm{kg}$ MS.

Table 4. Table reveals the average costs of concentrate, roughage, and complete diet per $\mathrm{kg}$ of dry matter $(\mathrm{DM})$ of lambs in finishing submitted to diets with licuri cake

\section{Animal Production and Environment}

Received on: 14/11/2018. Accepted on: 27/03/2019 Página |7 


\begin{tabular}{|c|c|c|c|c|}
\hline \multirow[t]{2}{*}{ Variables } & \multicolumn{4}{|c|}{ Licuri Cake inclusion levels(\% DM) } \\
\hline & 0.00 & 8.00 & 16.00 & 24.00 \\
\hline Concentrate $(\mathrm{R} \$ / \mathrm{Kg}$ of $\mathrm{DM})$ & 0.59 & 0.57 & 0.55 & 0.53 \\
\hline Roughage (R\$/Kg of DM) & 0.30 & 0.30 & 0.30 & 0.30 \\
\hline Complete Diet $(\mathrm{R} \$ / \mathrm{Kg}$ of $\mathrm{DM})$ & 0.89 & 0.87 & 0.85 & 0.83 \\
\hline Complete Diet (R $\$ /$ Animal/day) ${ }^{1}$ & 1.06 & 0.88 & 0.74 & 0.55 \\
\hline
\end{tabular}

${ }^{1}$ Cost in $\mathrm{R} \$$ per kg of DM $\mathrm{x}$ dry matter consumption per day.

Consequently, upon analyzing Table 4, one can evidently deduce that with higher inclusion of level of licuri cake, in the presence of soybean meal and milled corn grain, the total cost of the diets $(\mathrm{R} \$ / \mathrm{kg}$ of DM) reduces by $6.74 \%$. However, with the highest level of inclusion of licuri cake, the complete diet (R $\$ /$ Animal/day) reduces by $30.19 \%$, with the reduction being reflecting the decrease in the consumption component. Additionally, according to Table 4, the decrease in the cost of total feed/animal/day also reflects in the linear decrease $(\mathrm{P}<0.001)$ of the operational cost. Similarly, the gross avenue also decreased linearly $(\mathrm{P}<0.001)$ with the inclusion of licuri cake in the diet (see Table 5).

Table 5. Table presenting thefinancial return through average values obtained with the sale of lambs slaughtered according to the diets with licuri cake.

\begin{tabular}{|c|c|c|c|c|c|c|c|}
\hline \multirow[t]{2}{*}{ Variables } & \multicolumn{4}{|c|}{ Inclusion of LC (\% DM basis) } & \multirow[t]{2}{*}{ SEM ${ }^{1}$} & \multicolumn{2}{|c|}{ P-value } \\
\hline & 0.00 & 8.00 & 16.00 & 24.00 & & Linear $^{2}$ & Quadratic 3 \\
\hline $\mathrm{VPC}^{4}$ & 9.50 & 9.50 & 9.50 & 9.50 & - & - & - \\
\hline GR & 157.5 & 150 & 137.18 & 110.58 & 4.000 & 0.0001 & 0.1830 \\
\hline $\mathrm{OC}$ & 78.05 & 72.31 & 57.6 & 43.80 & 1.244 & 0.0001 & 0.1135 \\
\hline NOI & 79.46 & 77.7 & 79.58 & 66.79 & 3.000 & 0.1936 & 0.3777 \\
\hline OP & 50.24 & 50.88 & 57.56 & 59.43 & 1.022 & 0.0006 & 0.7659 \\
\hline $\mathrm{B} / \mathrm{C}$ & 1.02 & 1.10 & 1.38 & 1.53 & 0.054 & 0.0005 & 0.7564 \\
\hline LP & 8.22 & 7.61 & 6.06 & 4.61 & 0.131 & 0.0001 & 0.1146 \\
\hline
\end{tabular}

${ }^{1}$ SEM $=$ standard error of the mean; ${ }^{2}$ Similarity for linear effect; ${ }^{3}$ Significance for quadratic effect; ${ }^{4}$ Refer to the average value per carcase (Prices practiced in the region of Salvador-BA during the month of May 2011); VPC = value paid per carcass $(\mathrm{R} \$ / \mathrm{kg})$; GR = Gross Revenue (total $\mathrm{kg}$ of carcass $\mathrm{x} \mathrm{R} \$ / \mathrm{kg}$ of carcass); $\mathrm{NOI}=$ net operating income; $\mathrm{OC}=$ operating cost in $\mathrm{R} \$, \mathrm{OP}=$ operating profitability; $\mathrm{B} / \mathrm{C}=$ benefit and cost ratio; $\mathrm{LP}=$ leveling point; NOI= GR-OC; OP = GR-OC / GR x100; B/C = NOI/OC; LP $=\mathrm{OC} /$ price per $\mathrm{kg}$ of carcass.

On the contrary, the parameters of financial return such as (a) operating profitability $(\mathrm{OP}),(\mathrm{b})$ relation cost-benefit $(\mathrm{B} / \mathrm{C})$, and $(\mathrm{c})$ leveling point (LP), upon being analyzed showed a linear increase $(\mathrm{P}<0.001)$ with the increase of the licuri cake in the diet (see Table 6). In the same context, in Figure 2 , with the decrease in the cost of the feed, the factor that influences the operational cost to a large extent, the increase in the profitability has been witnessed.

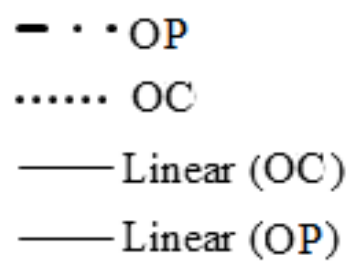


Figure 2.The figure displaying the operational cost and profitability (R\$) of finishing lambs submitted to diets with licuri cake.

Table 6: Table describing the operational cost and profitability of lambs submitted to diets with the luciri cake.

\begin{tabular}{ccccc}
\hline Variables & \multicolumn{4}{c}{ Licuri cake inclusion levels (\% DM basis) } \\
\cline { 2 - 5 } & 0.00 & 8.00 & 16.00 & 24.00 \\
\hline OC & 78.05 & 72.31 & 57.60 & 43.80 \\
OP & 50.24 & 50.88 & 57.56 & 59.43 \\
\hline
\end{tabular}

A close analysis of Table 1 and Table 4, draws attention towards the lower consumption of DM/animal/day, mainly reflected by the lower cost of the complete diet with the increase of the inclusion of licuri cake. This observation is found to be allied up with no difference in feed conversion between the levels of inclusion of licuricake tested (see Table 1) and at the lowest cost of the concentrate with an increase in the inclusion level (see Table 4). Apart from this, these aspects can also be witnessed in the linear decrease of the operational cost in the finishing of the animals, having a higher level of inclusion of licuri cake in their diet. Further, observation of a linear decrease in gross revenue, obtained from the sale of slaughtered animals, thereby indicates the difference in the lowering of gross revenue when diet without the inclusion of licuri cake, exhibiting a decrease in the range of
4.67 to $29.79 \%$, is being compared with the diet with inclusion of licuri cake, showing a $24 \%$ decrease. Thus, one can deduce that in the case of the diet with the inclusion of licuri cake presented lower gross revenue, in comparison to diet without the inclusion of licuri cake, owing to the lower weight of the cold carcass (see Table 1).

Essentially, the profitability, which mainly points out the proportion of gross revenue that constitutes a profit after covering the costs, showed an increase of $9.19 \%$ with the diet having the higher level of inclusion of licuri cake. The above increase in the profitability was observed due to two main reasons, (a) the lower price per kilogram of dry matter (see Table 4), and (b) lower consumption (see Table 1). Principally, profitability has been found to be coupled, with the revenue and cost composition, which in turn are found to be linked, with the reduction of the value of the diet with 
the lower consumption of the same. Consequently, variations in each productive scenario and diet ingredient relationships, as observed by Carvalho et al. (2007), might exist. The authors also outline that with respect to the sale of the lamb carcass, the profitability decreased linearly $(\mathrm{P}>$ $0.05)$ with the increase in the volume of the diet (lower cost). Indeed, the increase in the volume of the diet increased the weight, which induces a reduction in carcass weight slaughter, thereby reducing revenue more sharply than reducing costs.

On the other hand, the benefit and cost ratio (net operating revenue minus operating cost) get significantly influenced by the operating cost. The analysis has revealed that the operational cost, for the aspects already mentioned, decreases by $56.12 \%$ for the diet with the highest level of inclusion of licuri cake, in comparison to the diet without the inclusion of licuri cake. As a result, the net operating revenue (gross revenue minus operating cost), showed a difference of $21.22 \%$, thereby reflecting a greater benefit, being in the range of $40.20 \%$, for the diet with a higher level of inclusion of licuri cake. In the same context, Table 5 unveils that in the diet with a higher level of inclusion of the licuri cake, the minimum quantity of the carcass required for maintaining equality between revenue and costs was $4.61 \mathrm{~kg}$, which in turn refers to the occurrence of no losses. Contrastingly, at the $0 \%$ inclusion level of licuri cake, such leveling between revenue and costs would require $8.22 \mathrm{~kg}$ of the carcass. Therefore, these values are utilized as the leveling point, as it has been calculated by dividing the operational cost with the price per kilogram of the carcass. Thus, these values act as a financial indicator, thereby showing the amount of product's sale required for the full payment of the total costs (Agy et al., 2012).

In the beginning, the analysis of these financial parameters, illustrate that the lower operating cost upon replacing the soybean meal and ground corn grain with the licuri cake enables the use of this coproduct at the levels studied in the present work. However, for carrying out more appropriate analysis in order to make a judgment regarding the effective use of this co-product, it is highly imperative to point towards the smaller and linearly significant gross revenue (see Table 5), observed for the higher levels of inclusion of licuri cake owing to lower weight gain and consequent carcass gain. Further, with the help of a projection calculated using the economic analysis model, reported by Nogueira (2007), it has been manifested that the animals who were being offered diet having $24 \%$ of inclusion of licuri cake took 132 days to achieve the same weight gain (projecting the same gain average of the evaluated period) as the animals who were fed upon the diet without inclusion of 70day licuri cake. Even though the above projection highlights the difference in weight gained by animals fed upon diet with and without the inclusion of the licuri cake, it should be taken into account only on the demand of the market, concerning various characteristics of carcasses such as (i) carcass weight, (ii) size, and (iii) subcutaneous fat cover, thereby envisioning that the carcasses were not penalized, by the sudden rise of the price. Therefore, one can probably affirm that the inclusion of the same licuri, which do not favor the same weight of carcass, did not exert harmful effects on the characteristics of the carcass, which in turn reinforces that even lighter carcasses were being accepted by the slaughterhouse.

Thus, with respect to the prices of the ingredients evidenced in the diets used in the present work, the above results aid in ascertaining the advantage of the diet without licuri cake, if the producer is being focussed on the earlier finishing of the animals, as it allows to explore a greater number of production cycles. On the contrary, if one aims to achieve greater

\section{Animal Production and Environment}

Received on: 14/11/2018. Accepted on: 27/03/2019 Página | 10 
profitability on a timely basis, then a diet with the inclusion of licuri cake has been proven to be satisfactory. These observations, therefore, serves as a decisive factor, which assists the producer in making decisions regarding the use of the by product at the market cost of the concentrates at the time of use. These aspects, as indicated previously, also highlight that others can exert a significant impact on the termination of more lots in the same time period when fed upon a diet having no inclusion of licuri cake, only if there is an availability of space in the property for the confinement of lambs for the whole year. Additionally, the price per kilogram of the licuri cake, obtained in the present study as a value being similar to the kilogram of ground corn grain but differing significantly to the kilogram value of the soybean meal (see Table 2), demonstrates a point ratio which may vary in function acquisition at the time of actual use in a particular property.

Apart from the above considerations, it is also very essential to take into account that cake, used in the present study, were obtained from the extraction of oil used for the cosmetics industry as well as from the oil utilized for human consumption, but production being on a smaller scale as compared to the production of the biodiesel program. This may show influence in some studies, particularly, the study to increase the yield of this palm, which is about 2000 $\mathrm{kg}$ coconuts/ha/ year, in spite of the plausible increase in the production scale of licuri cake, thereby causing a reduction in per kilogram cost of the byproduct. However, at present, the production of licuri can be still identified as extractivist since some studies, reported in the literature, have described about the plantation and cultivation of this palm.

Further, Souza et al. (2014) have outlined that economically the feasibility of confinement for finishing lambs possess several impediments, as well as also states that the extension of the confinement period increases production costs to an extent that it reduces the profitability. However, minimization of the diet cost is possible, only if the use of by products in the diet would promote the compatibility of the nutritional level by considering the genetic potential of the animal, thereby meeting the demands of the market. Therefore, upon considering these variables, as being allied up with the financial, economic, management, one can achieve success in the enterprise by promoting the activity so as to make it economically viable.

Overall, in the present scenario, the major emphasis is not only on the production alone, as the practicability of the system has begun to strive for the maximum economic return, thereby making the activity profitable. Additionally, maximizing the control of the production costs is highly crucial, as it is directly related to the profit margin of the activity.

\section{CONCLUSION}

In a nutshell, the lower operational cost indicated by the values of the diet ingredients leads to highest profitability and the best benefit/cost ratio with the higher inclusion level of licuri cake (24\%). Consequently, according to these context, the use of this cake in diets for finishing lambs at the levels studied, in the present work, can be recommended. However, the economic viability will still depend on (i) the value of sorting the ingredients at the time of use, and (ii) the objectives of the production system taken into consideration.

\section{Animal Production and Environment}




\section{REFERENCES}

AGY, M.S.F.A.; OLIVEIRA, R.L.; RIBEIRO, C.V.D.M.;RIBEIRO, M. D.; BAGALDO, A. R.; ARAÚJO, G. G. L. de; PINTO, L. F. B.; RIBEIRO,R. D. X. Sunflower cake from biodiesel production fed to crossbred Boer kids. Revista Brasileira de Zootecnia. v.41, n.1, p.123-130, 2012.

AZEVEDO, R.A; RUFINO, L. M. A; SANTOS, A. C. R;SILVA, L. P; BONFÁ, H. C; DUARTE, E. R; GERASEEV, L. C. Performance oflambsfedwithinclusionof macaúba pie in the diet.

PesquisaAgropecuáriaBrasileira, v.47, p.1663-1668, 2012.

AOAC - Association of Official Analytical Chemistry. 1990. Official methods of analysis of the Association of Official Analytical Chemists. 15th edition. Washington.

AOAC - Association of Official Analytical Chemistry. 1998. Official methods of analysis of the Association of Official Analytical Chemists. 18th edition. Washington.

BARROS, N. N., de VASCONCELOS, V. R., WANDER, A. E.; de ARAÚJO, M. R. A. Bioenergy efficiency of lambs F1 Dorper x Santa Inês for meat production.Brazilian Agricultural

Research, v. 40, n. 8, p. 825-831, 2005. BORJA, M. S.; OOLIVEIRA, R. L.; RIBEIRO, C. V. D. M.; BAGALDO, A. R.; CARVALHO, G. G. P.; SILVA, T. M.; LIMA, L. S.; BARBOSA, L. P. Effectsoffeedinglicury

(Syagruscoronate) caketogrowinggoats. Asian-AustralasianJournalof Animal Science.Champaign, v. 23, n. 11, p. 1436-1444, 2010.

CARVALHO, S .; BROCHIER, M.A .; PIVATO, J .; VERGUEIRO, A .;
TEIXEIRA, R. C .; KIELING, R. Performance and economic evaluation of feed of confined lambs with diets containing different voluminous: concentrate ratios. Rural Science, v. 37, n. 5, 2007.

COSTA, J. B; OLIVEIRA, R. L; SILVA, T. M; RIBEIRO, R. D. X; SILVA, A. M; LEÃO, A. G; BEZERRA, L. R; ROCHA, T. C. Intake, digestibility, nitrogen balance, performance, andcarcassyieldoflambsfedlicuricake. Journal Animal Science, p. 1-8, 2016.

COSTA, J. B., OLIVEIRA, R. L., SILVA, T. M., BARBOSA, A. M., BORJA, M. S., de PELLEGRINI, C. B., OLIVEIRA, V. da S., RIBEIRO, R. D. X., BEZERRA, L. R.. Fatty acid, physicochemical composition and sensory attributes of meat from lambs fed diets containing licuri cake.

PloSone, v. 13, n. 11, p. e0206863, 2018.

FERREIRA, A. C. VIEIRA, J. F., BARBOSA, A. M., SILVA, T. M., BEZERRA, L. R., NASCIMENTO, N. G., FREITAS, J. E. de, JAEGER, S. M. P. L., OLIVEIRA, P. de. A., OLIVEIRA, R. L. Effect of replacing ground corn and soybean meal with licuri cake on the performance, digestibility, nitrogen metabolism and ingestive behavior in lactating dairy cows. Animal, v. 11, n. 11, p. 19571965, 2017.

GONZAGA NETO, S.; OLIVEIRA, R. L.; LIMA, F. H.; MEDEIROS, A. N.; BEZERRA, L. R.;VIÉGAS, J.; NASCIMENTO Jr, N. G.;FREITAS NETO,M. D. Milk production, intake, digestion, blood parameters, and ingestive behavior of cows supplemented with by-products from the 
biodiesel industry. TropicalAnimal

Health and Production, v. 47, p. 191200, 2015.

LICITRA, G.; HERNANDEZ, T. M.; VAN SOEST, P. J. Standardization of procedures for nitrogen fractionation of ruminant feeds. Animal Feed Science and Technology, v. 57, n. 4, p. 347358, 1996.

MEDEIROS, F. F.; SILVA, A. M. A.; CARNEIRO, H.; ARAÚJO, D. R. C.; MORAIS, R. K. O.; MOREIRA, M. N.; BEZERRA,L. R. Alternative protein sources derived from the biodiesel production chain for feeding to ruminants.Brazilian Archives of Veterinary Medicine and Zootecnia, v.67, p. 519-526, 2015.

MERTENS, D. R. Regulation of forage intake. Forage quality, evaluation, and utilization, 450-493, 1994.

MORAIS, R. K. O.; SILVA, A. M. A.; BEZERRA, L. R.; CARNEIRO, H.; MOREIRA, M. N.; MEDEIROS,F. F. In vitro degradation and total gas production of byproducts generated in thebiodiesel production chain. Acta Scientiarum, Animal Science, v.37, p.143-148,2015.

NATIONAL RESEARCH COUNCIL NRC..Nutrient requirements of dairy cattle.7th rev. 2001, ed. Natl. Acad. Press, Washington, DC.

NATIONAL RESEARCH COUNCIL NRC...Nutrient requirements of small ruminants.362p.,2007 ed. Natl. Acad. Press, Washington, DC.

NOGUEIRA, E. Análise de investimentos. In: BATALHA, M. O. (Coord). Gestão agroindustrial. São Paulo: Atlas, 2007. p. 223-224.
OLIVEIRA, R. L.; FARIA, M. M.; SILVA, R.; BEZERRA, L. R.;CARVALHO, G. G. P. de; PINHEIRO, A.; SIMIONATO, J.; LEÃO, A. G. Fattyacid profile ofMilkandcheesefromdairycowssupple mented a diet withpalm kernel cake. Molecules, v. 201, p.5434- 15448,2015.

RODRIGUES, M. D. M.; NEIVA, J. N. M.; de VASCONCELOS V. R.; LÔBO, R. N. B.; PIMENTEL, J. C. M.; MOURA, A. A. A. N. Utilization of cashew meal in the finishing of sheep in confinement.RevistaBrasileira de Zootecnia, v.32, n.1, p.240-248,2003.

SANTOS, E. O. Financial management ofsmallandmediumsized enterprises. 2 ed. São Paulo: Atlas, 2010.

SANTOS, G. J; MARION, J. C.; SEGATTI, S. Administration of Costs in Agriculture.

4 ed. São Paulo: Atlas, 2009.

SAS Institute Inc. SAS OnlineDoc® 9.1.3. Cary, NC: SAS Institute Inc., 2014.

SILVA, L. S.; BEZERRA, L. R.; SILVA, A. M. de A.; CARNEIRO, H.; MOREIRA, M. N.; OLIVEIRA, R. L. In vitro degradation and gas production of glycerin generated in the biodiesel production chain. Acta Scientiarum, Animal Science, v.37, p.265-272,2015.

SOUZA, M.R. de; VARGAS JÚNIOR, F.M. de; SOUZA, L.C.F. de; TALAMINI, E.; CAMILO, F.R. Economic analysis of the feedlot of lambs fed on piatã grass hay and soybean in natura or deactivated. Costs and @gronegócioonline, v. 10, n. 1, 2014. 
VAN SOEST, P. J.; ROBERTSON, J. B.; LEWIS, B. A. Methods for dietary fiber, neutral detergent fiber, and nonstarch polysaccharides in relation to animal nutrition. Journal of Dairy Science, v. 74, n. 10, p. 3583-3597, 1991.

VIANA, J. G. A.; REVILLION, J. P. P.; SILVEIRA. V. C. P. Alternativa de estruturação da cadeia de valor da ovinocultura no Rio Grande do Sul. Brazilian Journal of Regional Management and Development,v.9, n.1, p. 187-210, 2013. 